\title{
COMING ALIVE: SOME REMARKS ON THE RISE OF "MONOCHROME" SCULPTURE IN THE RENAISSANCE
}

\author{
Frank Fehrenbach
}

In his dialogue on sculpture, written in Padua shortly after 1500 , the sculptor-humanist Pomponius Gauricus touched upon polychromed metal sculpture. He explained not only how different alloys produce different colorations in bronze, but also how "coloracione" of gold, silver, yellow, green, and black is achieved during the finishing of the statue. ${ }^{1}$ Around the same time, however, Leonardo da Vinci explicitly excluded color from the discussion of sculpture. In his remarks on the competition between sculpture and painting, Leonardo boasted that sculpture requires "meno discorso" because it lacks the complications of color: "del colore nulla." ${ }^{2}$ Leon Battista Alberti's treatise on sculpture (actually, on the proportions of man and the production of statues on different scales) of about 1434-1435 contained no reference to color, although sculpture, according to Alberti, aims at the perfect imitation of natural bodies. ${ }^{3}$ Similarly, more than one hundred years later, in his Vite's elaborate introduction to painting, sculpture, and architecture, Giorgio Vasari did not mention polychromed marble and metal sculpture.

What appears, from the perspective of central and northern Italian art theory, to have been a divorce between color and sculpture over the course of the fifteenth and early sixteenth century was in reality a far more complicated process. The rise of monochrome sculpture is a fascinating back and forth, marked by surprising transitions, for- mal experiments, and increasing differentiation among sculptural materials. The orthodox juxtaposition of monochromy versus polychromy obstructs the view on far more interesting transitional phenomena. By the thirteenth and fourteenth centuries, ivory and alabaster statuettes showed an entire range of mono-, duo-, and polychromed surfaces. It is in this context that inventories indicate a new estimation of stone as material. Marble Madonnas are listed, for instance, as "ymagine beate Marie lapidis alabastri." ${ }^{4}$ Monochrome hardwood statuettes and small ivory altars became a specialty of Cologne at about the same time. Toward the end of the fifteenth century, the "breakthrough" of monochrome stone, bronze, limewood, and oak sculpture was largely a question of scale. As a general rule, we can say that the smaller the sculpture, the more usual it was to leave surfaces, especially of more precious materials, relatively untouched by color - though not, to be sure, without protective varnishes and glazes.

Around 1434, Donatello transformed the gray sandstone Cavalcanti Annunciation (Santa Croce, Florence) into a fictitious white-marble monument, carefully accentuated by some gilding. In this case, coloration is used foremost to create an almost monochrome surface in imitation of a more precious material. Donatello was the first for whom the application of color seemed to hinge on the distinction between noble and less noble materials. He did not hesitate to 
produce polychromed works in wood, terracotta, cartapesta (papier-mâché), stucco, or macigno (sandstone), but he was apparently among the earliest artists to renounce color on marble and bronze sculptures - a parallel to Brunelleschi's emphasis on the monolithic, unpainted columns in his Florentine basilicas. In his Saint George, Donatello seems to affirm monochromy's most crucial dilemma. In order to represent the gaze, the smooth surface of the eyes requires-in the absence of paint - a chisel that hollows out what is supposed to be flat and creates the illusion of a dark pupil, a violation of surface imitation in favor of an optical illusion. Even in the fifteenth-century reliefs of the Della Robbia workshop, which are the most direct predecessors to monochrome marble sculpture, indication of the gaze - and, therefore, the application of black color-was deemed indispensable.

What, then, drove the emergence of largescale monochrome sculptures in Europe around and after 1500? Evidently, the unearthing of spectacular monumental figures such as the Laocoön group in 1506 or the Apollo Belvedere in 1509 provided important paradigms, since these statues had lost their original colors during their long hibernation. ${ }^{5}$ However, this must already have been the case for most of the ancient statues that increasingly adorned Italian cities from the thirteenth century onward. As early as the ninth century, the Chludov Psalter prominently features paradigmatic "pagan" idols as monochrome statues on high columns (fol. 117r). In a French Boccaccio manuscript of the 1470 s, the famous ancient painter-sculptress Marcia produces monochrome sculptures and polychrome paintings. ${ }^{6}$ Was it only a more orthodox classisizing current that prompted late fifteenth-century sculptors to renounce colors?
In reality, the "invention" of large-scale monochrome marble sculpture dates to an earlier period. Its birthplace was central Italy, its birth date was circa 1300, and the artists involved were not sculptors, but painters. In the fresco cycles of the Upper Church of San Francesco in Assisi, here attributed to Giotto, monochrome statues on an implicitly large scale and in equally large numbers populate the pediments of Christian (!) buildings (Fig. 1). Shortly after 1300 , Giotto decorated the lower register of the Cappella degli Scrovegni in Padua with fourteen monumental personifications of Virtues and Vices. These are grisaille paintings representing nearly monochrome marble sculptures, evidently referring to large-scale classical reliefs in Rome, ${ }^{7}$ but also competing with the spare polychromy in the workshop of Giovanni Pisano. What makes some of Giotto's personifications in Padua particularly significant is the delicacy of their skin tones - e.g., Fides (Faith) - and their inventiveness or, better, their surreal nature. For example, Inconstantia (Inconstancy), a figure that appears to slip from its spherical support, provides an almost ironic contrast to the incarnation of sculptural firmness in its counterpart, Fortitudo (Fortitude). Inconstantia is an impossible sculpture, a contradiction in terms. The contradictory character is a dominant trait of Giotto's allegories, such as Invidia (Envy), a statue standing on fire, or Spes (Hope), a marble sculpture hovering midair, weightless and without support.

Giotto's monochrome sculptures appear as bravura demonstrations of the painter's skills, as do the fictitious niches (coretti) at the arch of the presbytery, with their eyecatching linear perspective. Monochrome statues in painting were transmitted from trecento Italy to the north toward the end of 


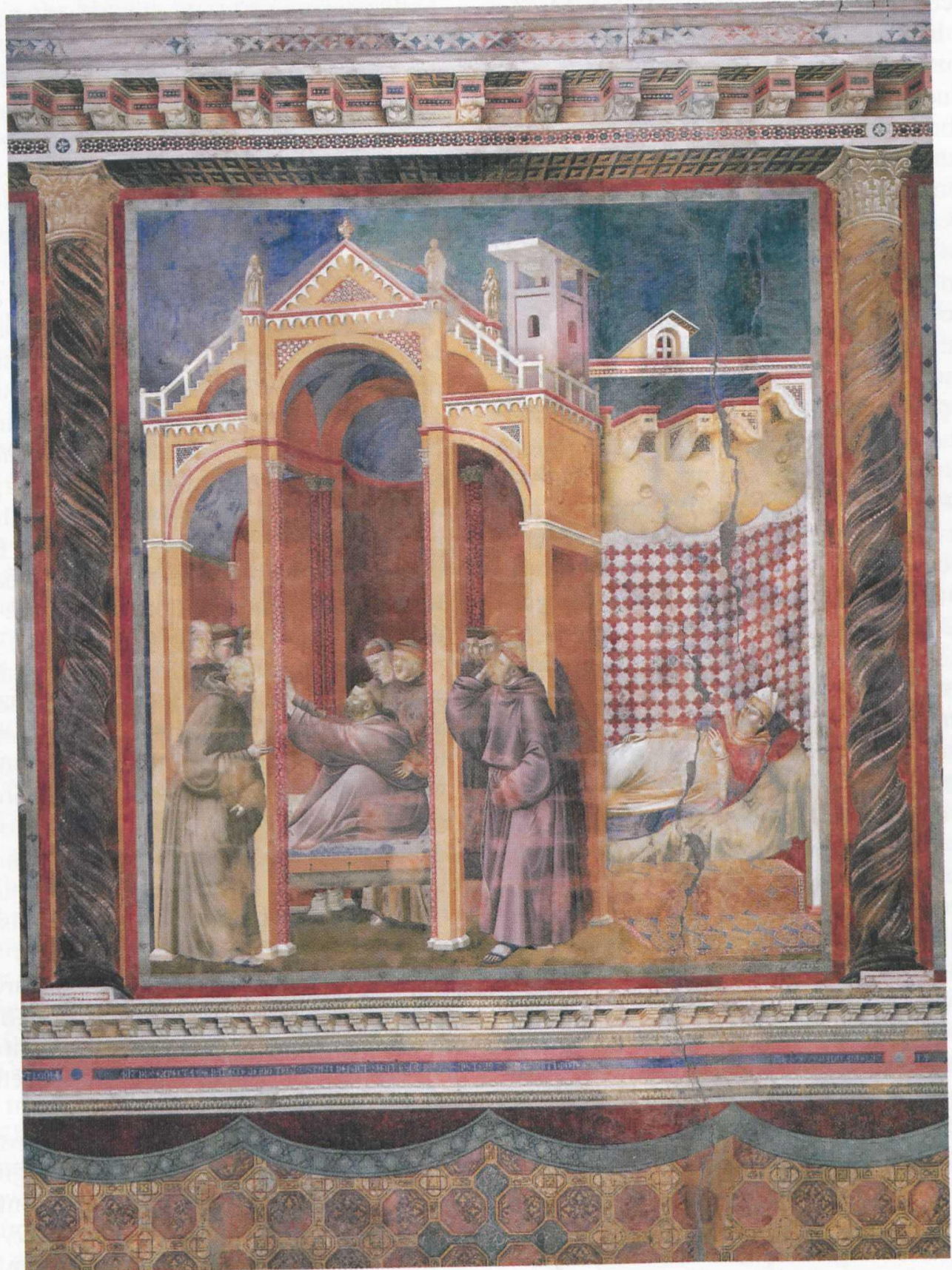

Fig. 1 Giotto (?), Vision of Fra Agostino and the Bishop of Assisi. c. 1295. San Francesco, Assisi. (Photo: copyright Stephan Diller, Würzburg) 
the century. In his Flight into Egypt (Musée des Beaux-Arts, Dijon, 1393-1399), Melchior Broederlam elaborated the genre, introducing a new and highly influential type: the broken monochrome (pagan) statue on a column of a different color. In his monochrome panel Throne of Mercy in Frankfurt, Robert Campin went even further. This lifesized figure group provokes a direct competition with contemporary virtuoso sculptures. Following a hypothesis by Molly Teasdale Smith, paintings such as this could be related to monochrome grisaille textiles covering altarpieces during Lent, a tradition mirrored in the differentiation between the outer, monochrome wings of triptychs, visible during workdays, and the brilliant colors of the three inner sides that were only exposed during feast days. ${ }^{8}$

Jan van Eyck's late Annunciation diptych in the Thyssen Collection offers a spectacular comparison with Giotto's paradoxical sculptures, perhaps as the only survivor of a larger group. The latter possibility is suggested by Jean, Duc de Berry's 1413-1416 inventory, in which one entry mentions a diptych "faiz de noir et de blanc." Since its feast day is celebrated during Lent, the Annunciation is an obvious choice for monochrome painting. But this does not explain the imitation-or, rather, anticipationof monochrome statues in an ambience that was still dominated by polychromed sculpture.

Following a hint from Erwin Panofsky, Rudolf Preimesberger interpreted van Eyck's painting as a document of the unwritten paragone, the competition of the arts, in the North. ${ }^{10}$ Concealing its true nature-a painted surface-the diptych demonstrates the overcoming of a particular difficulty. It could also refer to ancient paradigms. According to Pliny the Elder, Zeuxis produced highly esteemed black-and-white paintings ("pinxit et monochromata ex albo"). ${ }^{11}$ With the mirror effect of the white marble statues on the black touchstone (pietra di paragone) slab, van Eyck seems to have anticipated the later topos of the Italian paragone-challenged by Venetian painters after 1500 that painters are only able to show a single viewpoint.

With the detached flying dove of the Holy Spirit, van Eyck produced another paradoxical sculpture. Shortly thereafter, Rogier van der Weyden emphasized the "impossible" virtuosity of his fictitious sculptures in the Beaune Altarpiece, where he actually painted the small sculptural supports for the Virgin's delicate vase of lilies. However, with the protagonists' smooth, white eyes, van Eyck takes from the painting in terms of animation what he adds in terms of materiality. The diptych demonstrates marvelously and painfully that something is missing, that the sculptures are only about to unleash the dynamic impact of the sacred story, only about to see, move, and speak. With all their overwhelming fictive presence as marble bodies surrounded by different fictitious stones, these statues long for the moment of animation. In short, they bear testimony, ex negativo, to the true miracle of painting: its enlivening through color. ${ }^{12}$ Besides the representation of completely monochrome stone statues, experiments with all grades of their enlivening through subtle additions of color became a specialty of Early Netherlandish painting.

It is not the Living Stones of the Gospel, but Pygmalion who is the true paradigm of these experiments. In fourteenth-century manuscripts of the Roman de la Rose, the strokes of the sculptor in love-even the most explicit strokes-fail to animate his statue. ${ }^{13}$ It is a late thirteenth-century manu- 
script in the Vatican that demonstrates the basic requirements for enlivening and response: the veiling of the white statue with colorful vestments. ${ }^{14}$ Consequently, in many early modern descriptions of paintings, the vivacità (enlivening) of images relies upon color. Following the paradigm of Leonardo da Vinci, many painters, in Vasari's words, "gave life to their figures through color." 15

The cinquecento hero of enlivening through color was Titian. In a letter describing Titian's Venus and Adonis, Ludovico Dolce states: "It is not sufficient to form the figure by an excellent design, if the colors that should imitate flesh have a tone of porphyry or soil (terreno), and if they lack that union and delicacy and vivacity that nature produces in living bodies." ${ }^{16}$ In the face of these remarks, the trompe l'oeil of monochrome sculpture by painters provides a visible argument. This argument is about the power of painting to enliven the dead through color. The painted monochrome sculptures of Giotto and his followers demonstrate the ironic formula of a difficulty, the representation of stone sculpture, which could only be enlivened by overcoming a second difficulty, color. Through his imitative skills, the painter of monochrome sculptures produces a nonpainting that longs for painting.

It is exciting to see how sculptors turned the argument around yet again. They did, in fact, accept the limitations that painters imposed upon the sculptor's art, trying to become true magistri lapidum viventium, masters of the living stones. Sculptors attempted, in short, to turn a handicap into a triumph. The overcoming of self-imposed limitations is an important feature in the differentiation of the arts during the Renaissance. In one of his most famous sonnets, Michelangelo accepts the factual lifelessness of his marble
Notte and has it paradoxically say: "I am glad to sleep, and even more to be of stone, while turmoil and shame continue; not to see, not to hear is my consolation [. . .]" (Rime 247).

Monochrome sculpture tends to radiate a more mysterious life than its polychromed counterpart. We could call this effect the "emergence of life," a parallel to the traditional, Aristotelian view on the colors white and black as the "origins" of all color. This provides a powerful model not only for white marble, but also for dark bronze statues. Monochrome white and dark surfaces mark a point of departure for, rather than the absence of, enlivening. For Vincenzo Giustiniani, writing around 1630 , the disadvantage of monochrome sculpture becomes its major advantage, especially with regard to ancient sculpture that sometimes, "with so many unspeakable signs of life [. . .] appears to breathe, although he [the Meleager of the Vatican] is only of marble like the others." 17 Some thirty years later, Gianlorenzo Bernini makes the important statement, recalled in Paul Fréart de Chantelou's diary, that sculptors have to find equivalents of color in their monochrome sculptures - a major difficulty requiring more skill than the painter's. ${ }^{18}$

There is perhaps no more impressive anticipation of this statement than that provided by fifteenth- and sixteenth-century Italian marble reliefs and portrait busts. Again, the juxtaposition of monochrome versus polychrome sculpture appears as an oversimplification. After all, what does the term monochrome actually mean, considering changing conditions of illumination (flickering candles, different phases of daylight) and the reality of materials? We do not know exactly how Donatello's rilievi schiacciati ("flat reliefs"), Mino da Fiesole's busts, or Antonio Rossellino's Madonnas were polychromed 


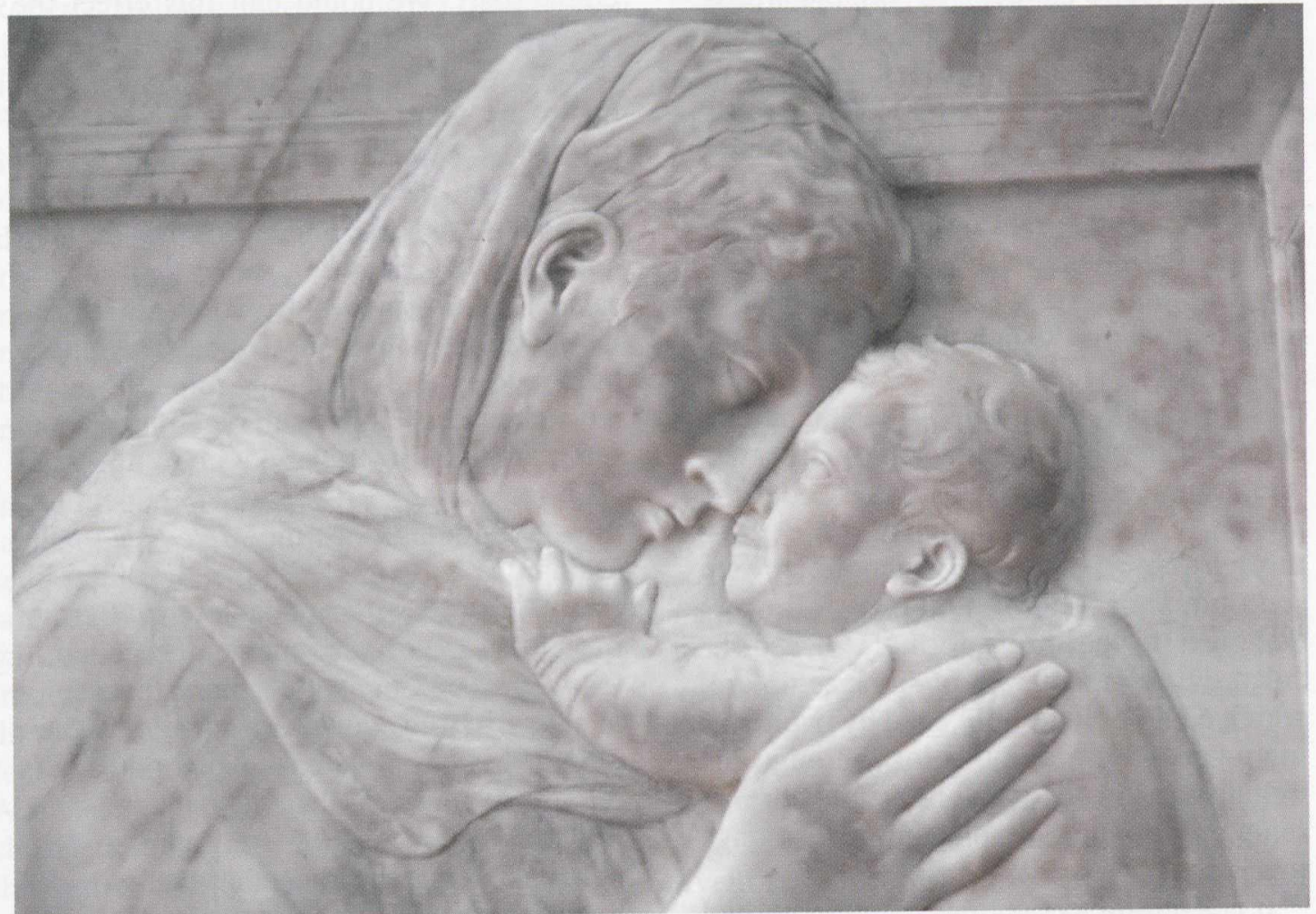

Fig. 2 Donatello, Pazzi Madonna. c. 1422. Bode-Museum, Berlin. (Photo: author, by permission of the Staatliche Museen zu Berlin, Stiftung Preussischer Kulturbesitz) 


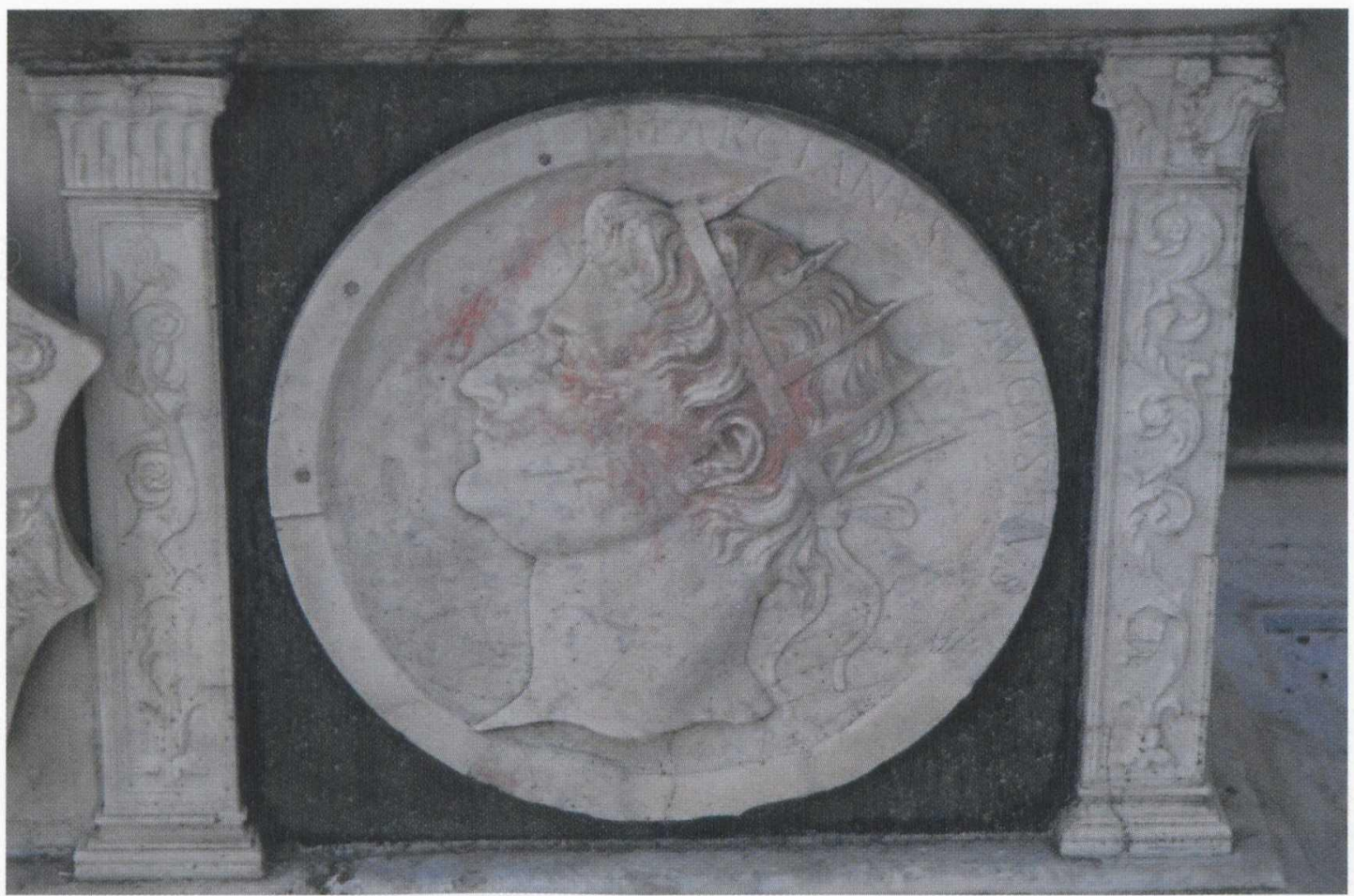

Fig. 3 Workshop of Giovanni Antonio Amadeo, Emperor Marcianus. c. 1490. Certosa di Pavia. (Photo: author)

or if and how delicately patina was added through varnish. But we can still see how these sculptors achieved the most marvelous effects of hue merely by differentiating more and less polished areas and by using the irregularly speckled marble block (Figs. 2 and 3). ${ }^{19}$

Bernini hinted at the astonishing effect of time on the surface of a marble statue; after nine to ten years, it begins to resemble the skin of a body. We do not really know whether the effect of skin provided by wax applications on some of his sculptures is a result of later interventions or whether they document an older, scarcely reflected tradi- tion (Vitruvius's "ganosis" or Daniele da Barbaro's "causis"), a tradition elaborated, for example, in Raffaele Borghini's "Modi di dar colore al marmore, acció sia simile all'antico." ${ }^{20}$ Sometimes the highly polished areas of skin reveal a deeper tone than the coarser surfaces of hair and garment, treated with a file, which appear much brighter. Before any pigment was added, these sculptors unleashed the virtual colors of the stone itself, and we witness with astonishment the marble's transformation into skin and flesh - soft, transitional, pulsating. In bronze casting, Pomponius Gauricus similarly alluded to the possibilities of subtly colored 
alloys to "shine through" the surface, thus providing the effect of living flesh. ${ }^{21}$ "Monochromy" thereby became another experimental field for the Western exploration of artistic enlivening as an oscillation between "dead" material and the fiction of an animated body, or of the emergence of the signs of life in art.

\section{NOTES}

1. Pomponius Gauricus, De sculptura, ed. Heinrich Brockhaus (Leipzig: F. A. Brockhaus, 1886), pp. 224, 236, 240, 242.

2. Leonardo da Vinci, Trattato della pittura 36.

3. Leon Battista Alberti, De statua 2: "[ . . ] veris naturae corporibus persimilima [sic] esse intuentibus appareant."

4. Anton Legner, "Polychrome und monochrome Skulptur in der Realität und im Abbild," in Vor Stefan Lochner: Die Kölner Maler von 1300 bis 1430, exh. cat. (Cologne: Wallraf-Richartz-Museum, 1977), p. 158.

5. See Patrik Reuterswärd, "The Breakthrough of Monochrome Sculpture during the Renaissance," Konsthistorisk tidskrift 69, nos. 3/4 (2000):125-149; Marco Collareta, "From Color to Black and White, and Back Again: The Early Middle Ages and Early Modern Times," in The Color of Life: Polychromy in Sculpture from Antiquity to the Present, ed. Roberta Panzanelli, Elke Schmidt, and Kenneth Lapatin (Los Angeles: Getty Museum, 2008), pp. 62-77.

6. New York Public Library, Spencer Coll., Ms 33, fol. 37v; see Hermann Ulrich Asemissen and Gunter Schweikhart, Malerei als Thema der Malerei (Berlin: Akademie Verlag, 1994), pp. 57-62.

7. Selma Pfeiffenberger, "The Iconology of Giotto's Virtues and Vices at Padua" (Ph.D. diss., Bryn Mawr College, 1966); Serena Romano, La O di Giotto (Milan: Electa, 2008), pp. 217-228.

8. Molly Teasdale Smith, "The Use of Grisaille As a Lenten Observance," Marsyas 8 (1957/1959):4354; cf. Marion Grams-Thieme, Lebendige Steine: Studien zur niederländischen Grisaillemalerei des 15. und frühen 16. Jahrhunderts (Cologne: Böhlau, 1988); Dagmar R. Täube, Monochrome gemalte Plastik: Entwicklung, Verbreitung und Bedeutung eines Phänomens niederländischer Malerei der Gotik (Essen: Die Blaue Eule, 1991).

9. Rudolf Preimesberger, "Zu Jan van Eycks Diptychon der Sammlung Thyssen-Bornemisza," Zeitschrift für Kunstgeschichte 54, no. 4 (1991):459-489 (cit. 460).
10. Ibid.; Erwin Panofsky, Galileo As a Critic of the Arts (The Hague: M. Nijhoff, 1954), p. 3. Hans Belting distinguishes between "physical" seeing (monochromy) and "imaginative" seeing (polychromy); see Hans Belting and Christiane Kruse, Die Erfindung des Gemäldes: Das erste Jahrhundert der niederländischen Malerei (Munich: Hirmer, 1994), pp. 6062.

11. Pliny, Naturalis Historia 35.64.

12. See Frank Fehrenbach, "Calor nativus-Color vitale: Prolegomena zu einer Ästhetik des 'Lebendigen Bildes' in der frühen Neuzeit," in Visuelle Topoi: Erfindung und tradiertes Wissen in den Künsten der italienischen Renaissance, ed. Ulrich Pfisterer and Max Seidel (Munich: Deutscher Kunstverlag, 2003), pp. 151-170.

13. Victor I. Stoichita, The Pygmalion Effect: From Ovid to Hitchcock (Chicago: University of Chicago Press, 2008), pp. 29-44 (fig. 17).

14. Bibliotheca Apostolica Vaticana, Urb. lat. 376, fol. 124v; see Eberhard König, Die Liebe im Zeichen der Rose: Die Handschriften des Rosenromans in der Vatikanischen Bibliothek (Stuttgart: Belser, 1992), p. 47 ; on the necessity to veil "naked truth" with colorful textures in poetry, see Petrarch, Epistolae Seniles 12.2.

15. Giorgio Vasari, Le vite de' più eccellenti pittori, scultori e architettori, nelle redazioni del 1550 e 1568 , ed. Rosanna Bettarini and Paola Barocchi, 6 vols. (Florence: Sansoni, 1966-1987), IV, p. 10.

16. Luigi Grassi and Mario Pepe, Dizionario dei termini artistici (Milan: TEA, 1994), pp. 1065-1066.

17. Vincenzo Giustiniani, Discorsi sulle arti e sui mestieri, ed. Anna Banti (Florence: Sansoni, 1981), p. 70; cf. Rudolf Preimesberger, "Motivi del 'paragone' e concetti teorici nel 'Discorso sopra la Scultura' di Vincenzo Giustiniani," in Caravaggio e $i$ Giustiniani: toccar con mano una collezione del Seicento, ed. Silvia Danesi Squarzina (Milan: Electa, 2001), pp. 50-56.

18. Paul Fréart de Chantelou, Journal de voyage du Cavalier Bernin en France, ed. Milovan Stanić (Paris: Macula, L'Insulaire, 2001), p. 47. 
19. For later examples of what I would call a refined "Marsyas effect" (the use of irregularly colored stones), see E. D. Schmidt's entries in Color of Life, pp. 143-144, 149-150.

20. See Kristina Herrmann-Fiore, "Osservazioni sull'epidermide di 'Apollo e Dafne' del Bernini," in OPD Restauro 8 (1996 [1997]):40-47 (esp. 43).

21. Pomponius Gauricus (p. 224): “[ . . .] Aristonidas [...] ferrum et aes miscuit, ut eius rubigine per nitorem aeris relucente, rubor exprimeretur verecundiae." 